\title{
Community - Based Tourism Development Model in the District of Pangandaran
}

\author{
Cecep Ucu Rakhman (Corresponding author) \\ Faculty of Humanities, Universitas Padjadjaran \\ Indonesia \\ E-mail: cecep.u.r@gmail.com
}

Dadang Suganda

Faculty of Humanities, Universitas Padjadjaran

Indonesia

Reiza D. Dienaputra

Faculty of Humanities, Universitas Padjadjaran

Indonesia

Sapta Nirwandar

Ministry of Tourism and Creative Economy

Republic of Indonesia

Received: January 21, 2014 Accepted: January 26, 2014 Published: February 13, 2014

doi:10.5296/ijch.v1i1.4970 URL: http://dx.doi.org/10.5296/ijch.v1i1.4970

\begin{abstract}
This research studies the process of community development activities in the tourism sector after the tsunami in Pangandaran. The majority of people in Pangandaran are helpless in tourism development activities, as part of the activities of the community, after the tsunami that occurred in 2006. This situation encourages the United Nations World Tourism Organization in
\end{abstract}


collaboration with the Ministry of Culture and Tourism of the Republic of Indonesia to implement community-based tourism development program in 2007. This research uses a qualitative approach. Method of data collection is conducted through in-depth interviews, field observations, and documentation study. Then, the collected data is used to perform triangulation process, verification, and interpretation with the elaboration of relevant theories. The results show that five aspects of the development of community-based tourism in Pangandaran through Enabling, Empowering, Protecting, Supporting, and Fostering are not optimal in the aspect of Fostering. This is due to the absence of a strong commitment to community development and intrinsic functions that should be implementing in an integrated manner, remains partial. In this research, it is found out that the empowerment and self-reliance are also determining by the controlling process to maintain the sustainability of empowerment and self-reliance of the community in the future. The result of this research is that development of community-based tourism in Pangandaran should use one more aspect, controlling to make sure the process is continuous.

Keywords: Community-based tourism, Pangandaran, Enabling, Empowering, Protecting, Supporting, Foresting, Controlling.

\section{Introduction}

The development of tourism in Indonesia for the last nine years, particularly regarding the number of International tourists and the incoming foreign exchange can be seen that the average of the changes has increased, as shown in the table 1 below.

Table 1. Number of international tourist visits to Indonesia and foreign exchange 2005-2013

\begin{tabular}{|c|c|r|r|r|r|}
\hline \multirow{2}{*}{ No. } & \multirow{2}{*}{ Year } & \multicolumn{2}{|c|}{ Number of International Tourist Visits } & \multicolumn{2}{c|}{ Foreign Exchange } \\
\cline { 3 - 6 } & & Visits & Change (\%) & in U.S. \$ & Change (\%) \\
\hline 1. & 2005 & 5002101 & -6.00 & 4521900000 & -5.75 \\
\hline 2. & 2006 & 4871351 & -2.61 & 4447980000 & -1.63 \\
\hline 3. & 2007 & 5505759 & 13.02 & 5345980000 & 20.19 \\
\hline 4. & 2008 & 6234497 & 13.24 & 7347600000 & 37.44 \\
\hline 5. & 2009 & 6323730 & 1.43 & 6297990000 & -14.29 \\
\hline 6. & 2010 & 7002944 & 10.74 & 7603450000 & 20.73 \\
\hline 7. & 2011 & 7649731 & 9.24 & 8554390000 & 12.51 \\
\hline 8. & 2012 & 8044462 & 5.16 & 9120850000 & 6.62 \\
\hline 9. & 2013 & 8802129 & 9.42 & 10054143828 & 10.23 \\
\hline
\end{tabular}

Sources: Ministry of tourism and creative economy, republic of Indonesia, and Indonesia statistics (BPS), 2014

From the table 1 we can see from 2005 until 2013, the number of international tourist visits had increased for seven years and foreign exchange had increased for six years. In 2005-2006 it decreased because of terrorist and bombing issue and in 2009 although the number of international tourist visits increased, but foreign exchange decreased because world financial 
crisis that made the international tourist spent money less than 2008.

One of the districts in Indonesia that has some prominent tourist attractions is Pangandaran, the New Autonomous Region District. Pangandaran District, the newly formed district, consists of 10 sub-districts and 93 villages. Pangandaran District has many kinds of tours, among other natural attractions (beach, sea, caves and natural reserves), culture performance (dance, puppets, and ceremonies), and special interests (sports, and kites). In addition, Pangandaran also has many in sighting and worth visiting tourist attractions: Pangandaran National Park, Green Canyon, Recreation Park of Nini Reef, Batu Karas Beach, Batu Hiu Beach, Cijulang Falls, Pananjung Nature Reserve, and Pangandaran Beach.

After the tsunami hit in July 2006, Pangandaran began planning the development of Community-Based Tourism (CBT) in late 2007. Pangandaran tourism development based is on the active participation of the community by developing ecotourism to conserve the environment because CBT is not simply a tourism business that aims at maximizing profits for investors. Rather, it is more concerned with the impact of tourism on the community and environmental resources. CBT emerges from a community development strategy, using tourism as a tool to strengthen the ability of rural community organizations that manage tourism resources with the participation of the local people (Suansri, 2003: 11).

\section{Research Methodology}

\subsection{Research Area}

The location of the research conducted by researchers is the Pangandaran District, because after Tsunami in July 2006, in this area there have been several groups that develop the tourism.

\subsection{Research Background and Field Conditions}

This research method is a qualitative research using case study research strategy, to find the facts with interpretations that depict the nature of some group or individuals phenomena derived from the findings in a particular place compared to the general phenomena in various places. The qualitative method is used to release comprehensively and naturally about how the process of policy is implemented, thus the purpose of selecting this qualitative method is to understand the process and to reveal the meaning of each phenomenon according to public perception using the existing supporting theories, afterwards framework is constructed. This research was carried out in several stages in terms of understanding social phenomena by differentiating, comparing, and classifying the object of research. According to Bogman and Taylor, as quoted by Moleong (1997:3), qualitative research method is the procedure of research that produces descriptive data in the form of written or spoken word from the behavior of those who can be observed. Qualitative research requires more guidance towards the preparation of substantive theory based on the data.

Case studies are used as a strategy that is more suitable when the subject of a research question with regard to how or why, when researchers have little opportunity to control the events that will be investigated, and where his research focus is on contemporary phenomenon (Yin, 2013:1). This is consistent with research conducted in the District of Pangandaran. The 
research was conducted at the arena and situation in which the interviews and observations took place. The Interviews with the informants were conducted at the informant's workplace with time and place agreed in advance. In order not to arouse suspicion, researchers always explained whom and for what purpose the interview was. The interview was followed by observation of the behavior of the objects narratives observed and supported by the information or opinions in the society in relation to the powerlessness and empowerment of the community in the District of Pangandaran. The observation process was conducted at the time of the interview.

\subsection{Research Instruments}

In this research, the instrument used in data collection when conducting combination of structured and unstructured in-depth interview, as well as the depth observations is researchers themselves. Stationeries, photo camera, and digital voice recording device supported the researchers as the instrument. The interview's material and in-depth observations were developed from the required data points that had been summarizing into the interview's guide as reference.

\subsection{Design and the Research Spokesman (informant)}

Research design focuses on the role and the experience of the informants, as well as how they view policy implementation. Informants also can describe phenomena, causal relationship, trends, and culture that develop in public institutions network. Each event or phenomenon is observed carefully because it has the potential to be used as key issues that enable researchers to provide an understanding of an issue that is more thorough about what he learned (Danim, 2002:61).

Researchers emphasize more on objectivity and fairness by explaining the purpose of the research to the informant. The appointed research informants are any person in any position related to the tourism community empowerment in Pangandaran whom are expected to provide information on the research subject. The procedure for determining the informants is based on the need (purposive), as well as the number of informants is determined based on information obtained saturation. A total of 29 informants interviewed in depth in this research is composed of a variety of backgrounds such as tourism activist groups (HPA Ilalang, Indecon, Kompepar, LWG), academicians (teacher, lecturer), businessmen (PHRI, ASITA), and representatives of government (Head of Tourism, Industry, Trade, Koperasi and SMEs Pangandaran District, Head of P2PAPKKBPMPD Pangandaran District).

\subsection{Data Collection Techniques}

There are five types of data collection techniques conducted by the researchers namely direct observation, in-depth interviews, documentary studies, group discussions, and triangulation of data. Explanations of each of the following data collection techniques are as follow.

\subsubsection{Direct observation}

This technique is carried out to obtain an overview of the research area. Besides, it is also to observe and analyze the process of interaction between active and passive participants in the 
development of tourism and tourist.

\subsubsection{In-depth Interviews}

Before conducting in-depth interviews, the researchers make interview pointers (outline) using interpretative approach. Key to the success of this approach lies in the ability of the researcher's relationship with the informants, for the informants know better and are closer to the people in the research site.

\subsubsection{Documentation Study}

In documentation studies, the researchers conduct the literature review of various documentations, documents/records that exist in the field of research, both formally stored in government and non-government office, owned formally or informally by any particular community members.

\subsubsection{Group Discussion}

Group discussions technique is conducted by collecting a number of informants from various circles. Through discussion, it is expected from the group to obtain useful information.

\subsubsection{Data Triangulation}

In the triangulation of data, the validity of the first data is to be doubtful, therefore they can be tested using other data from different sources, and so on, so that the data obtained are considered objective. The data triangulation can also be seen by its relation to the source. There are four ways to test the validity of data (Patton, 1987: 331 in Ratna, 2010:242), namely by:

(1) Comparing the obtained results of interviews, observations, and documents;

(2) Comparing the informants private recognitions with their statements in public, or in the group discussions;

(3) Comparing opinion at the time of the research (synchronization) along with the situations that have occurred throughout history (diachronic);

(4) Comparing the opinion of the educated, bureaucrats, and common people.

\subsection{Data Analysis Techniques}

The categorized data and information furthermore are interpreted and connected to the built mind frame and existing concepts or theories, resulting in relationship patterns or interactions between phenomena. Within this framework, the qualitative interpretation of the facts is also directed towards the phenomenon of the tourism community helplessness after the establishment of the tourism community empowering organization and the community empowerment process of the tourism sector in the District of Pangandaran.

\subsection{Research Objectives}

The research objectives are:

(1) Theoretically to obtain a new concept related to the community empowerment of tourism 


\section{Macrothink}

sector conducted by people who are qualified in carrying out the functions of society as a consequence of post-tsunami follow up in the development of tourism;

(2) Practically to get the best model suitably to be implemented in the District of Pangandaran, that intends to be a tourist district in Indonesia.

\subsection{Framework}

The development of community-based tourism in Pangandaran District requires a new structure in accordance with the socio-cultural life of the local community. This is necessary in order to achieve a balance between social, economic, cultural, and environmental. For these activities should be carried out continuously on an ongoing basis as a strategic step in the process of community empowerment is done through the process of enabling, empowering, protecting, supporting, and fostering.

The results of this research results in the theory of community-based tourism in view of the theory of empowerment, and a new structure of community-based tourism that can be implementing in the District of Pangandaran.

To make it easier to understand the framework, researchers make the flowchart in the following figure 1 .

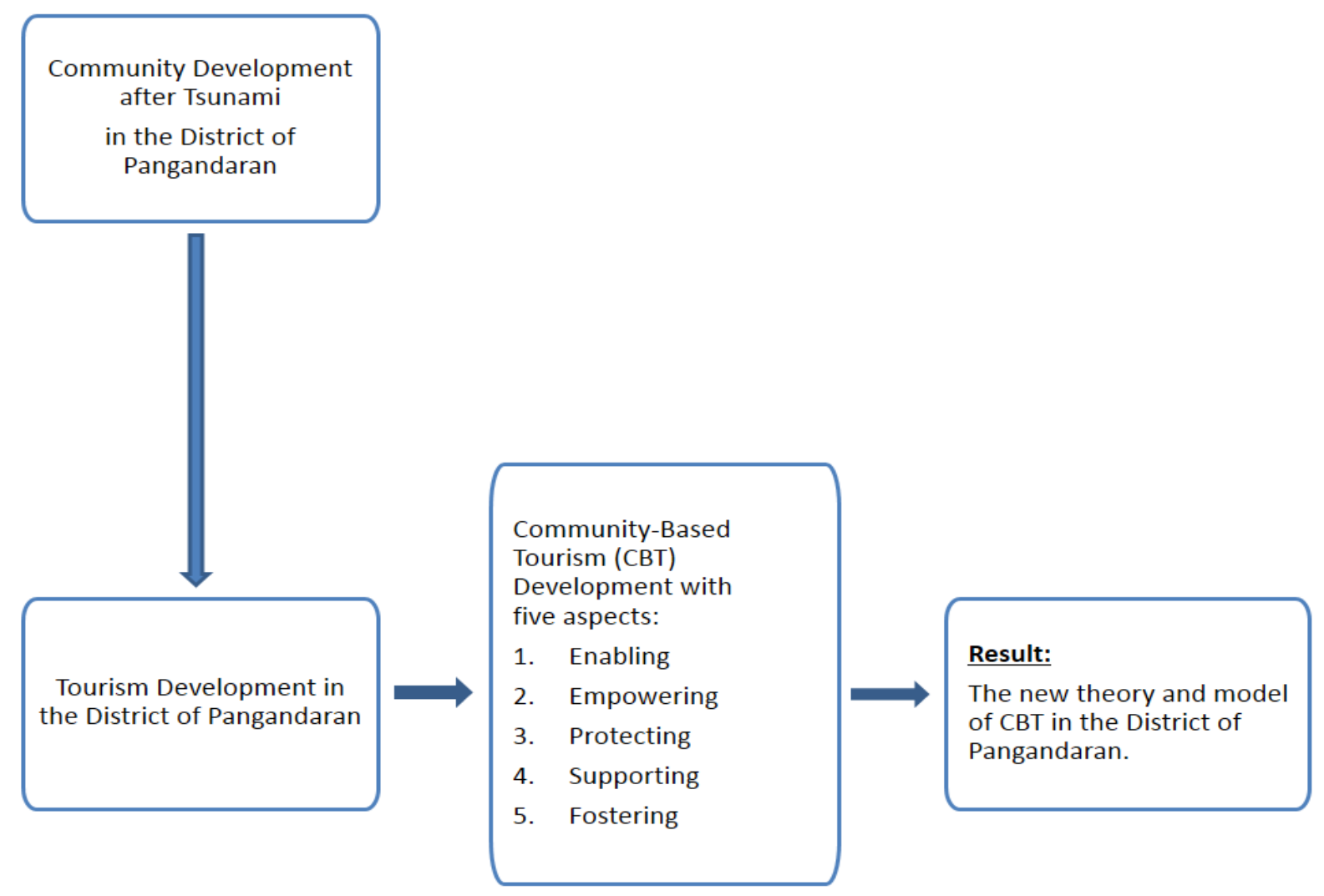

Figure 1. A flowchart shows the framework of the research.

\section{Tourism Development in the District of Pangandaran}

The development in the Pangandaran area began with the tsunami in July 2006 that destroyed 
most of the tourist areas. Tsunami waves caused more than 647 deaths, 456 residents reported missing, and destroyed 66 tourism facilities in Pangandaran. Severe impact of the tsunami on tourism facilities and a decline in the number of tourists have encouraged United Nations World Tourism Organization (UNWTO) to support countries affected by the tsunami, especially in the tourist areas (Wacik in Suhandy, 2010: 1).

UNWTO and the Ministry of Culture and Tourism, Republic of Indonesia (in October 19, 2011 becoming the Ministry of Tourism and Creative Economy, Republic of Indonesia) in 2007 have chosen and decided the qualified implementing agency to manage it. The next step is to identify and work with the key stakeholders, including holding regular meetings with the Pangandaran Tourism Working Group or the Local Working Group (LWG), and consultation with other stakeholders to ensure the identification of stakeholders, roles, and responsibilities of each party. One of the outputs is the community involvement plan, which is the plan to inform, provide outreach, get feedback, and involve broader stakeholders.

Together with the German government, the UNWTO has established a special unit in the City of Bonn, Germany to continue supporting countries with plan and implementation of sustainable tourism following the Guidelines on Biodiversity and Tourism Development Convention on Biological Diversity (CBD). Indonesia was elected to implement the Tourism Development on Supporting Biodiversity Conservation in 2007.

The Government of Indonesia through the Ministry of Culture and Tourism has agreed to cooperate and choose Pangandaran tourism area as the location of the project. The purpose of this program is to develop a Tourism Management Plan using a participatory approach to follow guidelines of the United Nations Environment Program (UNEP) on Biodiversity and Tourism Development CBD. UNWTO expects that the program focusing on the process of participatory planning in Indonesia with involving local communities, businesses, and local governments can be developed by the Indonesian government as a model for developing a sustainable tourism destination in Indonesia, which is recognized internationally.

Tourism Management Plan (TMP) in the Pangandaran area follows the UNEP Guidelines on Biodiversity and Tourism Development of the CBD adopted by the stakeholders in the Convention on Biological Diversity. These guidelines provide a framework for governments and stakeholders to plan and support the transition to sustainable tourism through education, capacity building, and consensus development process.

The guidelines emphasize the importance of stakeholder participation in all stages of the process from planning to implementation. From the process of planning to implementation uses several important approaches, namely (1) the ecosystem approach, and (2) the voluntary approach. When the process begins in Pangandaran, there are several activities, namely (1) determining the size and boundaries of the project site that will be managed, and (2) preparing a work plan, and identifying and establishing LWG.

In building partnerships with the local community, since 2007 Pangandaran has already had a working group of local tourism, which is an organization that is owned, managed and intended for the community in order to develop sustainable tourism called LWG. This local working 
group works to develop sustainable tourism by using a participatory approach in reference to the values of local wisdom. All activities are conducted in the initiation phase in three workshops at district level involving more than 40 participants from the government, private sector, and local communities. The main output of the workshop is the agreement on the participatory planning process to be taken, the logical framework of the project to develop Pangandaran, and the formation of LWG.

TMP for Pangandaran (2009-2018) is compiled jointly and adopted by those who are active in tourism at community level, the district government, the provincial government and the Ministry of Culture and Tourism. This is the first ever plan compiled for the tourist destination of Pangandaran (Suhandi \& Wita, 2013: 402). Since 2010, Pangandaran has been managed by using destinations governance or better known as the Destination Management Organization (DMO).

Both the TMP and DMO program launched by the Ministry of Culture and Tourism have all affected positively resulting in and the ever-increasing number of tourist visiting Pangandaran. The number of the incoming tourists visiting Pangandaran had increased and decreased according to its circumstances in the period of 2005-2013. After the tsunami in July 2006, the number of tourists dropped drastically. After starting the program initiated by the UNWTO and the Ministry of Culture and Tourism in the end of 2007, the total number of tourist arrivals into Pangandaran's tourism area was increasing again.

Number of tourist visiting Pangandaran has increased since 2008, after a program of interventions, including improving the image of Pangandaran through the printed press and electronic media activities involving the community to improve the environment. Learning about the number of tourists visiting Pangandaran in the period of 2005-2012 can be seen in the figure 2 (Suhandi \& Wita, 2013: 402-403).

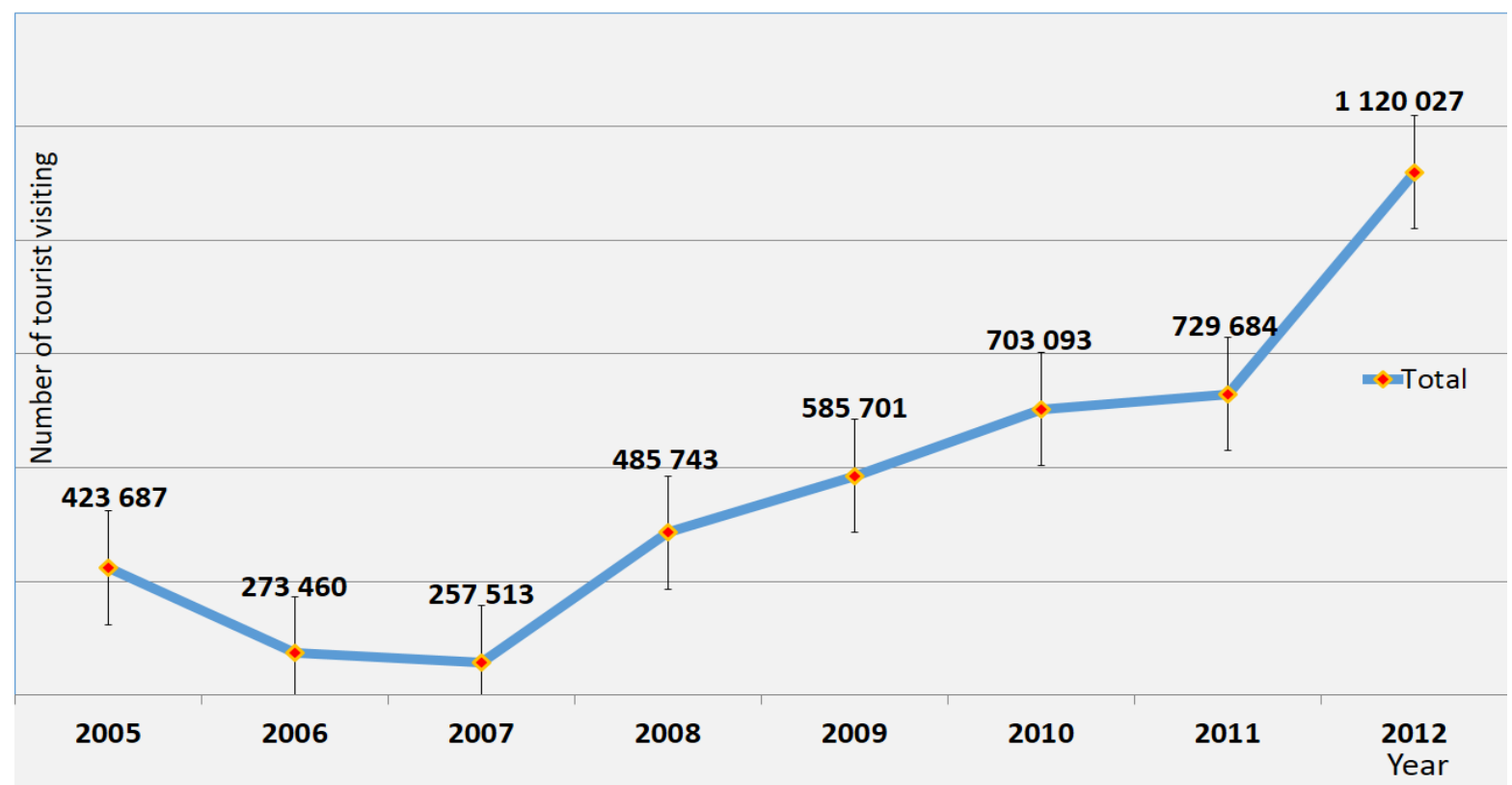

Figure 2. Growth of number of tourist visiting Pangandaran 2005-2012. 
The latest data from Head of Tourism, Industry, Trade, Koperasi and SMEs Pangandaran District about the total number of tourist visiting Pangandaran in 2013 is 1560740 visits, as well as the amount of revenues from the tourism sector amounted to U.S.\$ 326883.54 . International tourist visits increase from 1618 visits in 2006 to 8587 visits in 2013 (Suheryana, January 2, 2014).

According Suryadana (2010) in Prasiasa (2013:40), that refers to the establishment of destination tourism indicators which have high competitiveness as measured by an increase in inter - stakeholder partnerships in the development of destination, there are several challenges, among others:

(1) Lack of awareness among the actors in the tourism sector of the importance of partnerships in tourism development activities;

(2) The low support of legal instruments established by the regional manager;

(3) Lack of resources placed or allocated to strengthen the partnership program;

(4) Suspicion or lack of understanding among key partners partnership activities;

(5) Lack of a clear policy on partnership policies;

(6) The low setting of program activities/projects implemented, with partnership working scheme.

In the District of Pangandaran, awareness among the actors in the tourism sector of the importance of partnerships in tourism development activities is good. It is marked with a number of community or organization that is engaged in the development of tourism, among others Tourism Unit Management of Sukahurip Village, Forest Village Community Institution Bojong waterfall, and HPA Ilalang.

For a clear policy of partnership and support of the legal instruments, set by the regional manager of local government in this regard is still lacking or low. This happens because the old local government is more focused on the area of the original receipt of admission into a tourist attraction rather than make local regulations for the development of the existing tourist attraction. In addition, the formation of the new government of the District of Pangandaran, so it takes time to create a Regional Tourism Development Master Plan (Rippda) of Pangandaran District which refers to Rippda of West Java Province and the Indonesia Tourism Development Master Plan.

Similarly, the resource placed or allocated to strengthen the partnership program is still not good in terms of quantity and quality. In addition to suspicion or lack of understanding among the key partners of partnership activities, as well as the low setting in the implementation of program activities/projects with partnership working scheme makes Pangandaran District not be able to be a highly competitive destination.

\section{Community-Based Tourism Development in the District of Pangandaran}

\subsection{Enabling Aspects of Community-Based Tourism}

In this paper, enabling means to create an atmosphere or climate that allows the potential of the community to develop optimally. Empowerment should be able to free society from inhibited 
cultural and structural barriers (Suharto, 1997: 218-219).

Individually, human being has difficulties to create a situation that make conducive environment, which enables the human being to do the social and economic activities. It requires an authority that has a complete resource accommodating to the needs of the community by creating an enabling environment for people to conduct socio-economic activities.

One of the empowerment processes is to create an atmosphere or climate that is conducive for people to carry out socio-economic activities by considering the balance between the need to access the productive assets and the availability of existing productive assets. Thus, empowerment can be directed at a social transformation that takes place continuously or sustainably. After tsunami in Pangandaran, the weak and helpless people are possibly made strong and empowered with the community development programs on tourism sector. The community that previously had difficulties in meeting their needs now gradually recovers their empowerment and is economically independent.

Based on interviews with Sugema (December 22, 2013), Former Head of Tourism and Culture Ciamis District (Pangandaran previously under the rule of Ciamis District), said that in Pangandaran, strongly support the tourism economy of the community, the process of empowerment is quite good, it can be said that the process of enabling has been already well underway.

\subsection{Empowering Aspects of Community-Based Tourism}

Empowering means to strengthen the knowledge and capabilities of the community in solving problems and meeting their needs. Empowering should be able to develop all the skills and confidence to support their independence society (Suharto, 1997: 218-219). In this aspect of empowering the knowledge and capabilities of Pangandaran District can get better and capable to solve problems.

Suharto (2010:63-64) says that the success of community empowerment can be seen from the empowerment regarding their economic ability, the ability to access welfare benefits, as well as cultural and political capabilities. These three aspects are associated with the four dimensions of power, namely the power within, the power to, power over, and the power with.

When the confidence of the people who support self-reliance gets higher and tends to be overconfident, it sometimes becomes anticlimactic towards tourists. For instance, the food and beverage vendors with over confidence raise the price of drinks more than $100 \%$. This has led to the tourists disappointments towards the seller of the products in Pangandaran tourist area, and they will probably buy from outside of the tourist area that has a normal price product in their second visit.

According Ndraha (2003:76), powerless people have the right to access programs or activities conducted by government empowerment, because when the individuals in a society experience helpless or powerless conditions, the central government or local governments have obligation 
to empower them as one of the principal functions attached to government and it cannot be avoided.

Based on interviews with Natalia who is Chairman of the Campernik Community (January 21, 2014), the reality in Pangandaran District shows that it has been touched and empowered by community empowerment programs or activities conducted by the central government so that the process of developing community-based tourism is getting stronger. In the 2011 it was held training and managing used plastic waste to make as crafts, among other bins, bags, and wallets.

\subsection{Protecting Aspects of Community-Based Tourism}

Protection means to protect the public, especially vulnerable groups to avoid unequal competition with powerful ones, especially unhealthy competition between the strong and the weak, and to prevent exploitation of the strong against the weak group. Empowerment should be directed at the elimination of all kinds of discrimination and domination that are not profitable for the less people (Suharto, 1997: 218-219).

The indicator used is the legal and political awareness of Pangandaran District community (Schuler, Hashemi \& Riley in Suharto, 2010:63-64). In fact, most people already know about Pangandaran District on the rights and obligations associated with legal and political. It is characterized by the presence of the Presidium of the organization that succeeded in realizing the establishment of Pangandaran District administration, the number of existing community organizations, and the number of candidates from Pangandaran District in 2014.

In fact, in the District of Pangandaran, community is more aware and able to protect themselves from the strong group by forming communities. Many communities or groups of people make up the organization in order to develop tourism in Pangandaran District, among others Campernik, HPA Ilalang, and Forest Village Community Institution Bojong waterfall.

\subsection{Supporting Aspect of Community-Based Tourism}

The meaning of supporting here is to provide guidance and support for people to be able to carry out the each role and duty. Empowerment must be able to support the people from falling into becoming weak in position and being marginalized (Suharto, 1997: 218-219).

The indicator used is the community involvement in campaigns and protests against something that is considered incompatible with the norms prevailing in the local community (Schuler, Hashemi \& Riley in Suharto, 2010:63-64). In fact, people in the District of Pangandaran have been involved in the protest by mothers' recitation of the existence of immoral blocks that provide access to prostitution in the tourist area of Pangandaran beach. In addition to the protest, citizens have been placing banners on the side of the road-to-road conditions that connect one tourist attraction to tourist attraction to another, such as from the Pangandaran coast in the sub-District Pangandaran to the Green Canyon in the sub-District Cijulang.

In this case, there is indeed a supporting process and people's participation is emerged through the tourism development program of the government, especially the central government. It is expected that although the program will be discontinuing in the future, the people who have 
been empowered and independent can provide guidance and support to the rest of the community.

\subsection{Fostering Aspect of Community-Based Tourism}

The meaning of fostering here is to maintain conducive situation to stay balanced. In this case, the potential of the community should be maintained and preserved by the balance on sustainable work, so that people will not lose their business opportunity (Suharto, 1997:218-219 in Suharto, 2010: 67-68). Moreover fostering can also be interpreted as maintaining a balance between the need for accessing productive assets and the availability of existing productive assets.

In the District of Pangandaran, the current conditions are not conducive, because the people only actively participate in the beginning of a program of an external party which is referred to as external stimuli. Furthermore, if there are no programs and activities, people tend to be passive. In many programs, local activities turns then stops after stimulation is stopped (Soetomo, 2013: 120).

One example of conducive conditions which is not maintained is when tourists want to access the needs of productive assets such as a tour guide. In several attractions, there are no guides available, so that sometimes people who are not experts as guides, taking the role. This lead to decreasing of service quality and in the long term it will reduce the interest people to come back.

Also in Pangandaran District, many hotel owners are outsiders. This means the theory that says the benefits of tourism is more on side with the owners of capital, primarily from people outside the tourism destination is correct (Brechin, 1991; Brandon, 1992 in Prasiasa, 2013:114).

\subsection{New Model of Community-Based Tourism Development}

Implementation and the achievement of community-based tourism development goals from empowerment process theory can be achieved through the application of the approach five aspects: enabling, empowering, protecting, supporting, and fostering (Wrihatnolo \& Dwidjowojoto, 2007:117). A new concept derived from the research is the process of controlling as an aspect of community-based tourism in determining the empowerment and self-reliance in specific local contexts. The research community-based tourism development in the District of Pangandaran is a need for an additional aspect, which controls to make sure the process, is continuous.

Therefore, the dialectic of this research is originating from a conventional thesis on the development of tourism, which then leads to the antithesis of community-based tourism development with five aspects, and ultimately results in the synthesis of community-based tourism development with six aspects, as shown in the figure 3 below. 


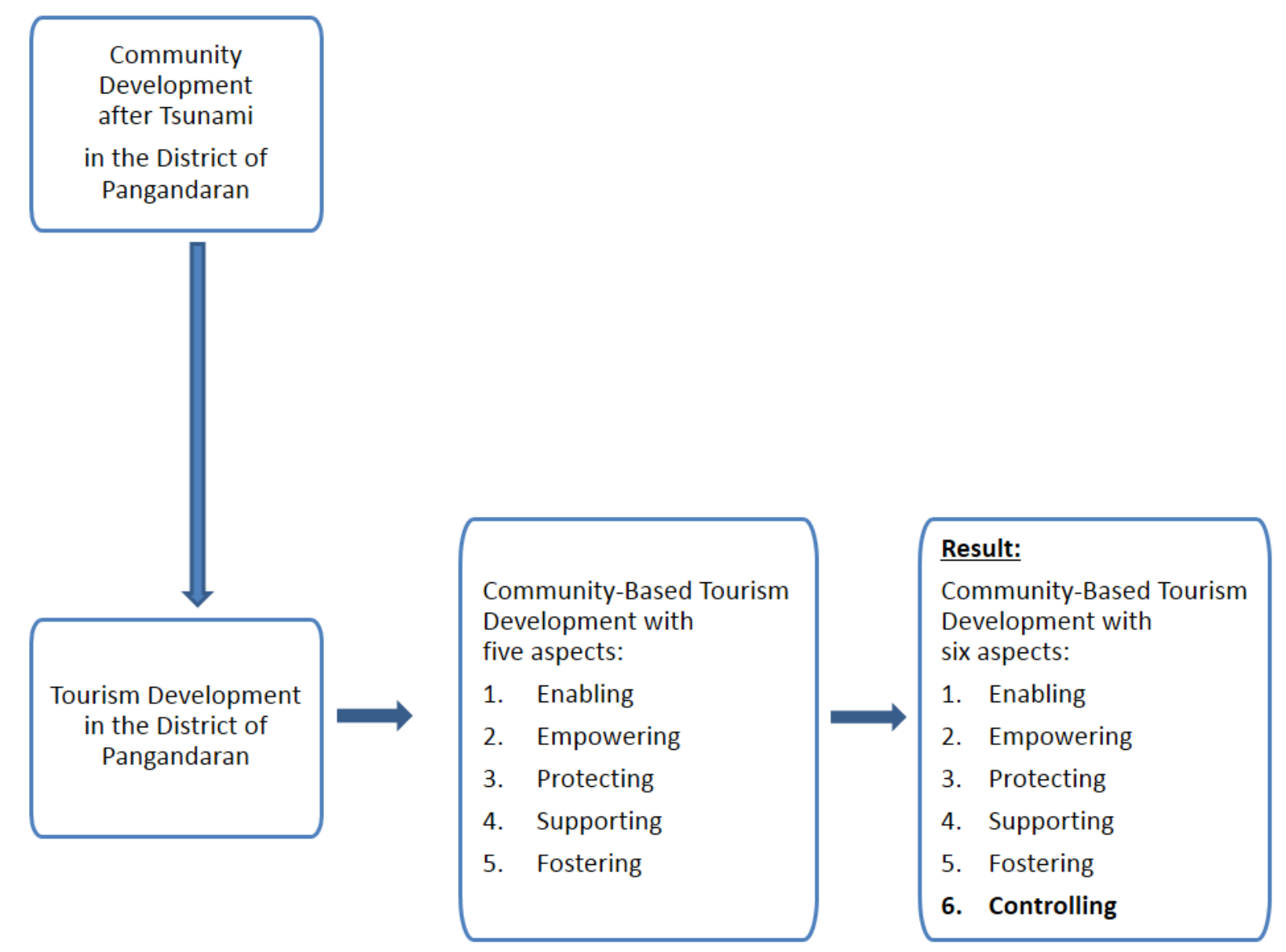

Figure 3. A flowchart show the result of the research.

\section{Conclusion}

Community-based tourism in Pangandaran District has been able to realize the empowerment and self-reliance of the Pangandaran community on economic level, so that people can adapt to other alternative and more productive business. It is because of the well implementation of the community-based tourism aspects on enabling, empowering, protecting, and supporting. Fostering is the only aspect that has not been well implemented, for the lack of commitment and intrinsic function of community empowerment that is still partially implemented and focused on building functions with emphasis on infrastructure development. A new concept derived from the research is the process of controlling as an aspect of community-based tourism that also determines the empowerment and self-reliance in a specific local context.

\section{Acknowledgement}

The research is financed by The Ministry of Culture and Tourism, Republic of Indonesia with the Letter of the Learning Task No. DL.008/4/21/Ro.2/KKP/2011.

\section{References}

Danim, S. (2002). Being a Qualitative Researcher. Bandung: CV. Pustaka Setia.

Moleong, L. (1997). Qualitative Research Methodology. Bandung: PT. Remaja Rosda Karya. 
Ndraha, T. (2005). Kybernology: Some Major Construction. Tangerang: Sirao, Credentia Center.

Prasiasa, D. P. O. (2013). Destinations Community-Based Tourism. Jakarta: Salemba Humanika.

Ratna, N. K. (2010). Research Methodology: Cultural Studies and Social Sciences Humanities in General. Yogyakarta: Pustaka Pelajar.

Soetomo. (2013). Community Empowerment: Could appear antithesis? Yogyakarta: Pustaka Pelajar.

Suansri, P. (2003). Community Based Tourism Handbook. Thailand: Responsible Ecological Social Tour - REST.

Suharto, E. (1997). Development, Social Policy and Social Work: Spectrum Thought. Bandung: Lembaga Studi Pembangunan STKS (LSP-STKS).

Suharto, E. (2010). Building a People's Community Building. Bandung: PT. Refika Aditama.

Suhandi, A. (2010). Pangandaran Tourism Management Plan. Pangandaran: Indonesia Ecotourism Network.

Suhandi, A., \& Simatupang, W. (2013). Towards a New Era of Sustainable Tourism in Pangandaran - Post Tsunami Disaster. In F. Teguh, \& R. Avenzora (Eds.), Ecotourism and Sustainable Tourism Development in Indonesia - The Potential Lessons and Best Practices (pp. 397-417). Jakarta: PT. Gramedia.

Wrihatnolo, R. R., \& Dwidjowojoto, R. N. (2007). Management Empowerment. Jakarta: Elex Media Komputindo.

Yin, R. K. (2013). Case Study: Design and Methods. Jakarta: RajaGrafindo Persada. [Online] Available: http://www.bps.go.id (January 5, 2014).

\section{Glossary}

Association of The Indonesia Tours and Travel Agencies (ASITA): Launched in Jakarta on January 7th 1971, ASITA is the only legally acknowledged non-profit alliance of Indonesian travel entrepreneurships. Operating under the RI Law No. 9/1990 regarding Tourism, ASITA provides headship to the communal efforts of Indonesian travel agencies.

Campuran runtah yang dibikin unik (Campernik): Mothers community formed from 2008 to collect and manage waste plastic used for handicraft souvenirs from Pangandaran. Currently more often provide training to the tourists who are interested to learn.

Himpunan Pencinta Alam (HPA) Ilalang: A nature lover organization, that aims to preserve the environment. The activity is planting mangroves on the Pangandaran coast. This activity is used as a tourist attraction.

Indonesian Tourism Network (Indecon): Non-profit organizations engaged in the development and promotion of ecotourism in Indonesia. Established in 1995, Indecon much help and 
facilitate public, private, and government for the development of ecotourism.

Kelompok Penggerak Pariwisata (Kompepar): One element of "community tourism" is committed to assist the government in developing tourism. Kompepar formed through the initiative of the community to participate and help develop the tourism potential of the local area.

Perhimpunan Hotel dan Restoran Indonesia (PHRI): An employer' organization hotels and restaurants scattered throughout Indonesia.

P2PAPKKBPMPD: A unit of work in Pangandaran District government in charge of Women Empowerment, Child Protection, Control Population, Family Planning, Community Development and Village Government.

\section{Appendix}

Picture 1. Meeting between the DMO Committee with administrators youth club, discuss preparation of scenario structuring tourist destination in the New Year holiday 2014 (December 27, 2013).

Picture 2. Meeting between the DMO Committee with student volunteers, discuss the evaluation of the preparation of scenario structuring tourist destination in the New Year holiday 2014 (December 27, 2013).

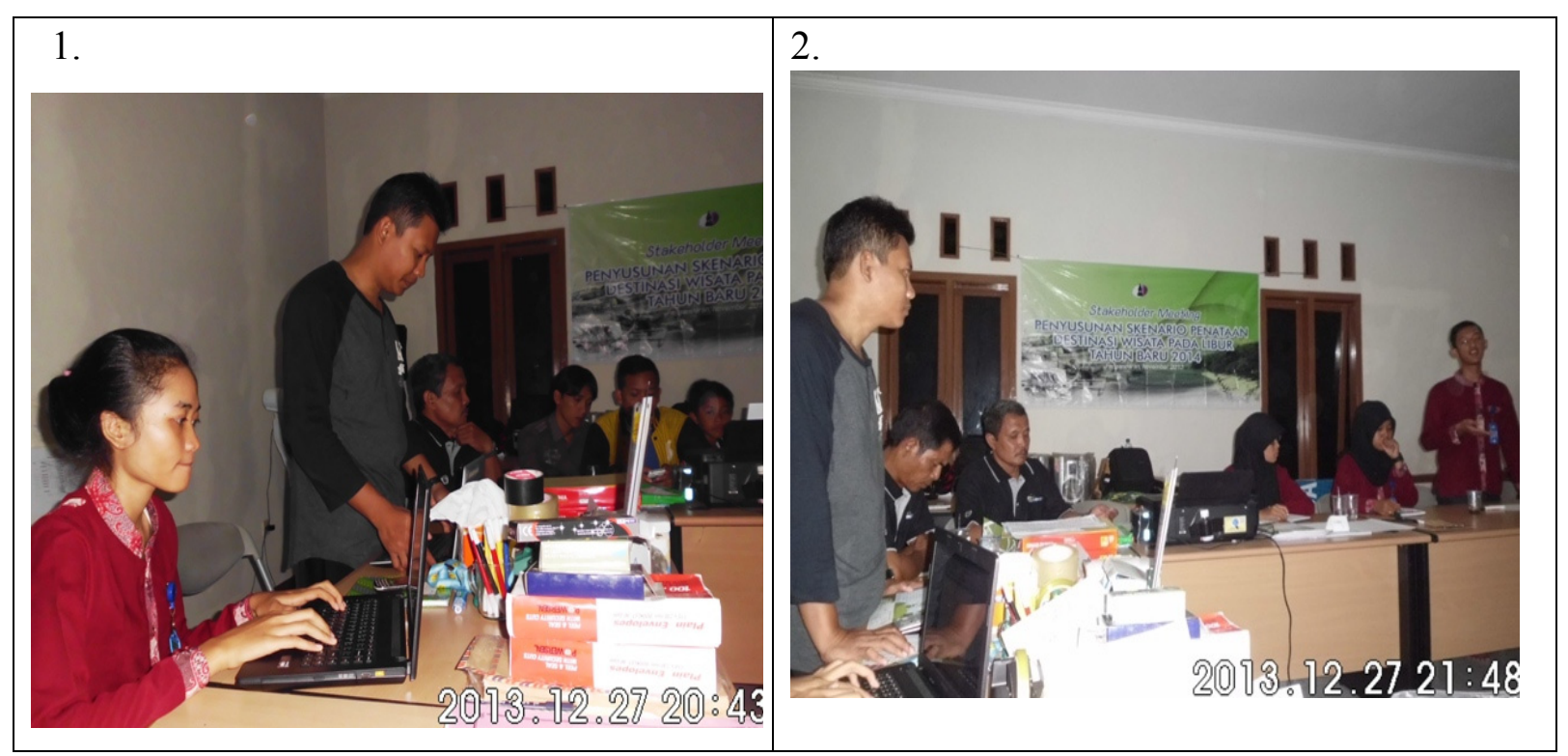

Picture Pangandaran beach situation in the morning, visited by many domestic tourist. 3. (January, 1, 2014).

Picture Meeting between the DMO Committee with administrators Bojong waterfall, 4. discuss about a new tourism attraction development in Pangandaran called Curug Bojong (December, 28, 2013). 


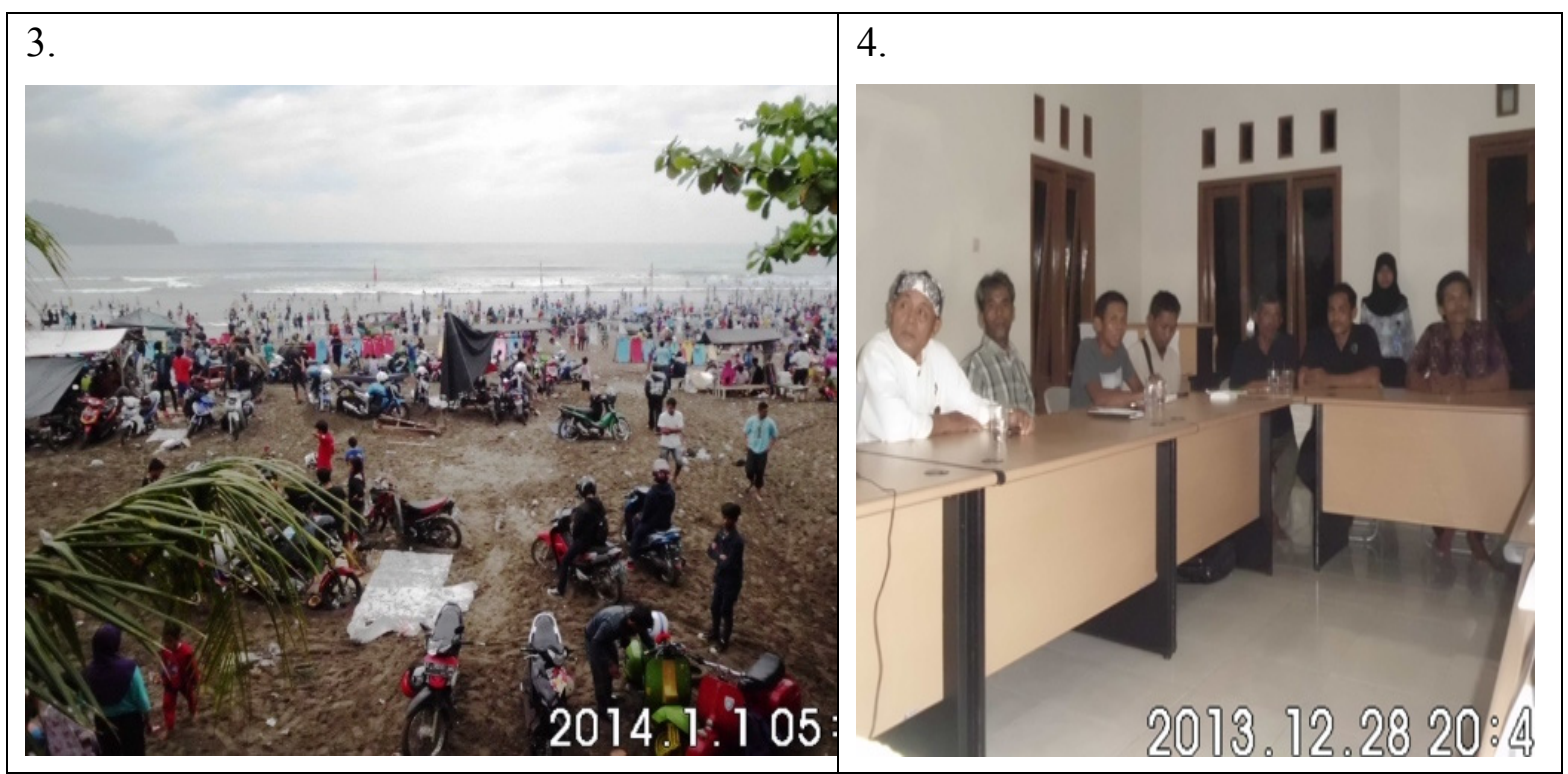

Picture Curug Teko (Valley of Teapot) in Curug Bojong (January 15, 2014).

5.

Picture Curug Batu (Valley of Rock) in Curug Bojong (January 15, 2014).

6.

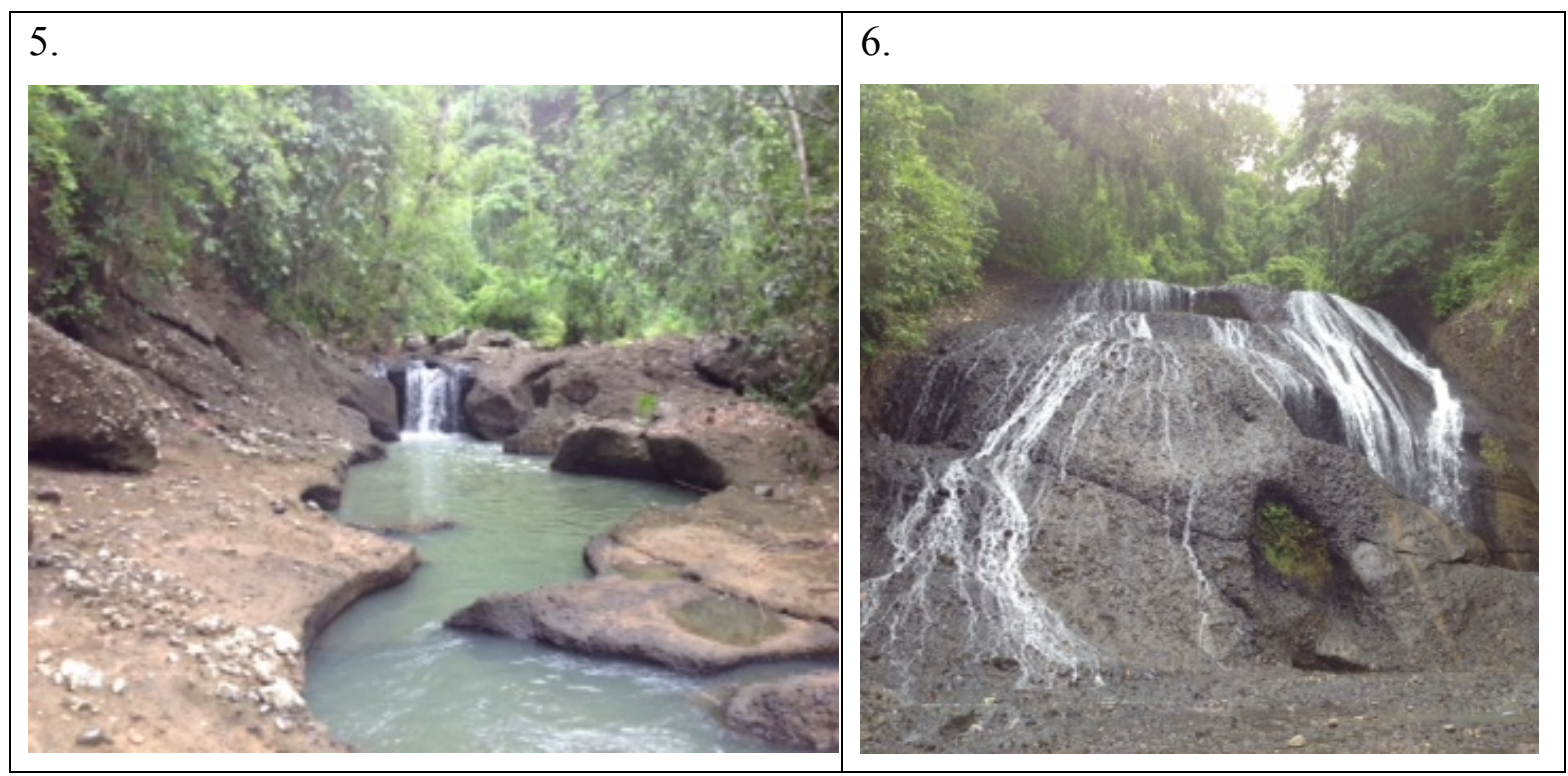

Picture Sustainable Tourism through Energy Efficiency with Adapting and Mitigation

7. Measures (STREAM) Program in the Green Belt Bulaksetra, Babakan village, Pangandaran (January 23, 2014).

Picture One of the products made by Campernik community that uses plastic garbage 8. $\quad$ to be made handicrafts like a bag. (January 21, 2014). 


\section{Macrothink}

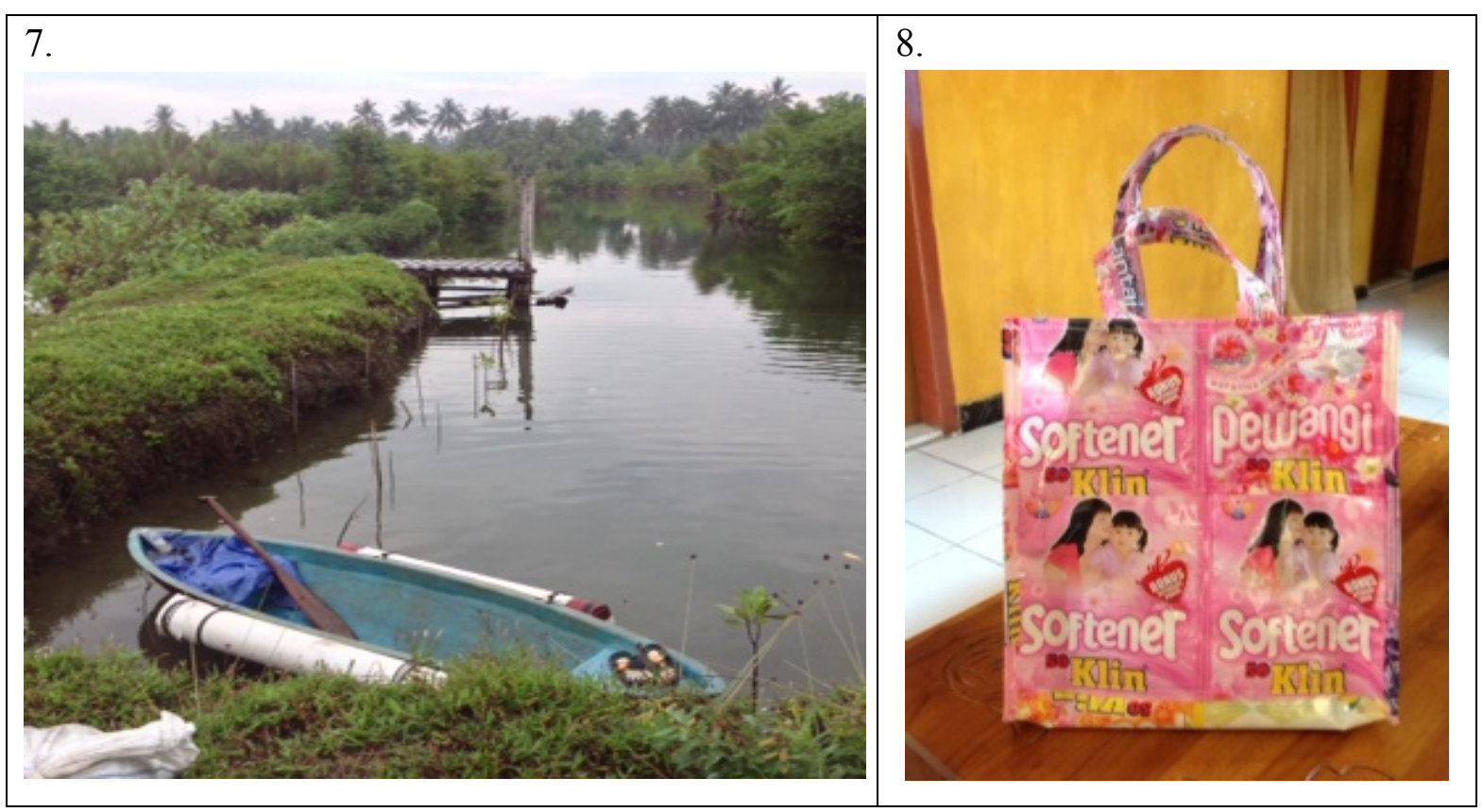

\section{Copyright Disclaimer}

Copyright reserved by the author(s).

This article is an open-access article distributed under the terms and conditions of the Creative Commons Attribution license (http://creativecommons.org/licenses/by/3.0/). 